\title{
OBSERVASI PENGKAJIAN RESEP SECARA ADMINISTRATIF PADA APOTEK X DI KABUPATEN BADUNG
}

\author{
Putu Rika Jesika Putri ${ }^{1}$ \\ ${ }^{1}$ Program Studi Farmasi, Fakultas Matematika dan Ilmu Pengetahuan Alam, \\ Universitas Udayana \\ Email: rjesikaputri15@gmail.com
}

\begin{abstract}
ABSTRAK
Pengkajian Resep merupakan salah satu pelayanan kefarmasian di Apotek yang diatur dalam Permenkes RI No. 73 Tahun 2016. Penelitian ini bertujuan untuk mengetahui implementasi salah satu standar pelayanan kefarmasian yaitu pengkajian resep di salah satu apotek di Kabupaten Badung. Jenis penelitian ini bersifat deskriptif observasional. Pengambilan data dilakukan dengan cara retrospektif (data resep obat bulan Januari-Mei 2020) di Apotek X di Kabupaten Badung dengan total 70 resep. Berdasarkan hasil identifikasi pengkajian resep secara administratif, persentase kejadian ketidaklengkapan resep di apotek X yaitu nama pasien 2,86\%, umur pasien $45,71 \%$, jenis kelamin $87,14 \%$, berat badan 97,14\%, alamat pasien 51,43\%, SIP (Surat Izin Praktek) dokter 42,86\%, nomor telepon $14,28 \%$, paraf dokter $40 \%$ dan tanggal resep 7,14\%. Kelengkapan resep dokter belum memenuhi ketentuan kelengkapan admnistratif resep menurut Permenkes RI No. 73 Tahun 2016.
\end{abstract}

Kata kunci: Pengkajian resep, Implementasi, Apoteker, Apotek

\begin{abstract}
Prescription screening is one of the pharmaceutical care standards in Pharmacy which regulated in Permenkes RI No. 73 Tahun 2016. The aim of this research is to know about the implementation of one pharmaceutical care standard which is prescription screening in one of the pharmacies in Badung Regency. This research is a descriptive observational. Data collection was performed by means of a retrospective (drug prescription data in January-May 2020) in X Pharmacy at Badung Regency with a total sample of 70 prescriptions. Based on the result of administrative screening of prescription, the percentage of incompleteness prescription at pharmacy $\mathrm{X}$ are patient name 2,86\%, patient age $45,71 \%$, gender $87,14 \%$, body weight $97,14 \%$, patient address $51,43 \%$, doctor's license (SIP) $42,86 \%$, phone number $14,28 \%$, physician initial $40 \%$ and prescription date $7,14 \%$. The doctor's prescription completeness has not fulfilled the administrative prescription completeness requirement according to Permenkes RI No. 73 of 2016.
\end{abstract}

Keywords: Screening recipies, Implementation, Pharmacist, Pharmacy

\section{PENDAHULUAN}

Farmasi forensik adalah aplikasi dari ilmu farmasi yang berhubungan dengan masalah hukum [1]. Menurut Saferstein, forensic science adalah aplikasi atau pemanfaatan ilmu pengetahuan tertentu untuk penegakan hukum dan peradilan [2]. Berdasarkan ilmu farmasi forensik, apoteker terlibat dalam pekerjaan profesional yang berkaitan dengan litigasi, proses pengaturan, atau sistem peradilan pidana [1]. Pelayanan kefarmasian adalah bentuk pelayanan dan tanggung jawab langsung profesi apoteker 
dalam pekerjaan kefarmasian untuk meningkatkan kualitas hidup pasien. Apotek merupakan tempat dilakukannya praktik kefarmasian oleh Apoteker. Peraturan yang mengatur mengenai standar pelayanan kefarmasian di Apotek yaitu Peraturan Menteri Kesehatan No. 73 Tahun 2016. Semua tenaga kefarmasian yang bertugas di apotek dalam menjalankan tugasnya wajib mengacu pada standar pelayanan kefarmasian yang telah ditetapkan ini.

Pelayanan obat atas resep dokter merupakan salah satu pelayanan kefarmasian di Apotek. Resep merupakan hal terpenting sebelum pasien menerima obat. Berdasarkan Permenkes No. 26/ Menkes /Per/I/I/1981 menyebutkan bahwa resep harus ditulis dengan jelas dan lengkap. Aturan dasar mengenai penulisan resep telah disebutkan pada Kepmenkes No. 280/ Menkes /SK /V /1981 yang menyatakan bahwa resep harus memuat [3]:

a. Nama, alamat dan nomor izin praktek dokter, dokter gigi atau dokter hewan

b. Tanggal penulisan resep.

c. Tanda R/ pada bagian kiri setiap penulisan resep.

d. Setelah tanda R/ harus ditulis nama setiap obat atau komposisi obat.

e. Tanda tangan atau paraf dokter penulis resep, sesuai dengan peraturan perundang-undangan yang berlaku.

f. Tanda seru dan paraf dokter untuk resep yang mengandung obat yang jumlahnya melebihi dosis maksimal. g. Nama pasien, umur dan alamat pasien.

h. Jenis hewan dan nama serta alamat pemiliknya untuk resep dokter hewan.

i. Untuk penderita yang memerlukan pengobatan segera, dokter dapat memberi tanda "segera", "cito", "statim" atau "urgent" pada bagian atas kanan resep.

j. Pada resep yang tidak dapat diulang, resep asli diberi tanda "n.i", "ne iteratur" atau "tidak boleh diulang".

Dalam alur pelayanan resep, apoteker wajib melakukan pengkajian resep sesuai dengan Peraturan Menteri Kesehatan No. 73 Tahun 2016, yang meliputi pengkajian admninstratif, kesesuaian farmasetis, dan kesesuian klinis untuk menjamin legalitas suatu resep dan meminimalkan kesalahan pengobatan. Resep harus ditulis dengan jelas untuk menghindari salah persepsi antara penulis dengan pembaca resep, kegagalan komunikasi dan salah interpretasi antara dokter dengan apoteker merupakan salah satu faktor kesalahan medikasi (medication error) yang berakibat fatal bagi pasien.

Berdasarkan Surat Keputusan Menteri Kesehatan RI No. 1027 /MENKES/SK/IX/2004, medication error adalah kejadian yang merugikan pasien akibat pemakaian obat selama dalam penanganan tenaga kesehatan yang sebetulnya dapat dicegah [4]. Medication error terdiri dari prescribing error (kesalahan peresepan), dispensing error (kesalahan penyiapan obat), dan administration error (kesalahan 
administrasi). Dari ketiga jenis medication error tersebut, fase prescribing memiliki risiko kesalahan paling besar, yaitu sebesar 99,12\% [5]. Prescribing error yang sering terjadi adalah administrasi resep yang tidak lengkap, penggunaan singkatan yang tidak lazim, dan penulisan aturan pakai yang tidak jelas. Walaupun demikian prescribing error dapat pula terjadi pada aspek farmasetik berupa bentuk sediaan, stabilitas dan aspek klinis berupa polifarmasi, interaksi obat.

Komponen skrining administratif yang berpotensi menimbulkan error adalah umur pasien 62\%, jenis kelamin pasien $100 \%$, berat badan pasien $100 \%$, SIP dokter $100 \%$, alamat pasien $99,43 \%$, paraf dokter $19 \%$, serta tanggal resep 1\%. [6].

Tingginya permasalahan medication error pada fase prescribing menunjukkan perlunya tindakan nyata untuk mengurangi kejadian tersebut agar dapat dihindari hal-hal yang merugikan bagi pasien. Untuk itu farmasis memiliki peran strategis dengan cara dilakukannya skrining resep.

Berdasarkan masalah tersebut, dilakukan pengkajian terhadap kelengkapan administratif pada resep apakah memenuhi ketentuan kelengkapan pengkajian resep menurut Peraturan Menteri Kesehatan No. 73 Tahun 2016 tentang Standar Pelayanan Kefarmasian di Apotek. Objek dalam penelitian ini yaitu Apotek X yang berada di wilayah Kabupaten Badung, Provinsi Bali.

\section{METODE PENELITIAN Bahan dan Peralatan}

Kumpulan data pada penelitian ini atau sampel adalah resep dokter di Apotek X pada bulan Januari - Mei 2020. Penelitian dilakukan di salah satu apotek di daerah Jimbaran, Badung.

\section{Metode}

Penelitian ini bersifat deskriptif, yaitu mendeskripsikan secara sistematis, faktual dan akurat terhadap suatu populasi atau daerah-daerah tertentu, mengenai sifat-sifat dan faktor-faktor tertentu Penelitian ini dilakukan dengan melihat resep di apotek, kemudian dicatat pada tabel pengumpulan data. Jenis data penelitian ini retrospektif, yaitu penelitian yang dilakukan sekarang berdasarkan kumpulan data dari masa lalu.

Pengolahan data dilakukan dengan menghitung jumlah resep yang berpotensi menimbulkan medication error fase prescribing. Setelah didapatkan nilai perhitungan tersebut, selanjutnya pengolahan data dilakukan dengan pendekatan kuantitatif, yaitu untuk melihat berapa besar persentase prescribing error yang terjadi dalam resep yang ada di Apotek di Kabupaten Badung dengan menggunakan Microsoft Office Excel, kemudian disajikan dalam bentuk tabel.

\section{HASIL dan PEMBAHASAN}

Penelitian ini telah dilaksanakan pada bulan Juni 2020 di Apotek X. Apotek $\mathrm{X}$ merupakan salah satu Apotek yang terletak di Kabupaten Badung dengan 2 tenaga kefarmasian yaitu 1 apoteker dan 1 orang teknis 
tenaga kefarmasian (TTKS) yang bertugas melakukan pelayanan kefarmasian. Pada penelitian jumlah sampel resep yang diteliti yaitu 70 resep. Hasil persentase kelengkapan administratif dari resep dokter bulan Januari - Mei 2020 hasilnya diuraikan pada Tabel 1.

Resep adalah permintaan tertulis dari seorang dokter kepada apoteker pengelola apotek untuk menyiapkan dan atau membuat, meracik, serta menyerahkan obat kepada pasien. Yang berhak menulis resep adalah dokter, dokter gigi dan dokter hewan [7]. Pengkajian resep merupakan tahap pemeriksaan awal yang harus dilakukan oleh apoteker setelah resep diterima. Tiga aspek yang perlu diperhatikan dalam pengkajian resep yaitu syarat administratif, syarat farmasetis dan pertimbangan klinis [8].

Dalam penulisan, resep biasanya terdiri dari 6 bagian, yaitu:

a. Inscriptio: Nama dokter, no. SIP, alamat/ telepon/HP/kota/tempat, tanggal penulisan resep. Untuk obat narkotika hanya berlaku untuk satu kota provinsi. Sebagai identitas dokter penulis resep. Format inscriptio suatu resep dari rumah sakit sedikit berbeda dengan resep pada praktik pribadi.

b. Invocatio: permintaan tertulis dokter dalam singkatan latin "R/ = resipe" artinya ambilah atau berikanlah, sebagai kata pembuka komunikasi dengan apoteker di apotek. c. Prescriptio/ Ordonatio: nama obat dan jumlah serta bentuk sediaan yang diinginkan.

d. Signatura: yaitu tanda cara pakai, regimen dosis pemberian, rute dan interval waktu pemberian harus jelas untuk keamanan penggunaan obat dan keberhasilan terapi.

e. Subscrioptio: yaitu tanda tangan/ paraf dokter penulis resep berguna sebagai legalitas dan keabsahan resep tersebut.

f. Pro (diperuntukkan): dicantumkan nama dan umur pasien. Teristimewa untuk obat narkotika juga harus dicantumkan alamat pasien (untuk pelaporan ke Dinkes setempat)

Pada penelitian ini, pengkajian resep yang dilakukan hanya pengkajian administratif resep saja. Berdasarkan Peraturan Menteri Kesehatan No. 73 Tahun 2016, aspek administratif pada resep mencakup nama pasien, umur, jenis kelamin dan berat badan pasien; nama dokter, nomor SIP (Surat Izin Praktek), alamat, nomor telepon dan paraf dokter; dan tanggal penulisan resep [8].

Pada Tabel 1. diketahui bahwa skrining administratif pada resep di Apotek X wilayah Badung sebagian besar komponennya belum mencapai $100 \%$ hanya nama dokter dan alamat dokter yang mencapai $100 \%$. Ketidaklengkapan suatu resep dapat berpotensi terjadinya medication error. Sehingga efek yang diinginkan oleh pasien tidak tercapai [9]. 
Tabel 1. Pengkajian Kelengkapan Administratif Resep di Apotek

\begin{tabular}{cccccc}
\hline No & $\begin{array}{c}\text { Pengelompokan } \\
\text { Kelengkapan } \\
\text { Administratif }\end{array}$ & Ada & Tidak Ada & Ada & Tidak Ada \\
\hline 1. & Nama Pasien & 68 & 2 & $97,14 \%$ & $2,86 \%$ \\
2. & Umur Pasien & 38 & 32 & $54,29 \%$ & $45,71 \%$ \\
3. & Jenis Kelamin & 9 & 61 & $12,86 \%$ & $87,14 \%$ \\
4. & Berat Badan & 2 & 68 & $2,86 \%$ & $97,14 \%$ \\
5. & Alamat Pasien & 34 & 36 & $48,57 \%$ & $51,43 \%$ \\
6. & Nama Dokter & 70 & - & $100 \%$ & $0 \%$ \\
7. & SIP Dokter & 40 & 30 & $57,14 \%$ & $42,86 \%$ \\
8. & Alamat Dokter & 70 & - & $100 \%$ & $0 \%$ \\
9. & No. Telepon & 60 & 10 & $85,72 \%$ & $14,28 \%$ \\
10. & Paraf Dokter & 42 & 28 & $60 \%$ & $40 \%$ \\
11. & Tanggal Resep & 65 & 5 & $92,86 \%$ & $7,14 \%$ \\
\hline
\end{tabular}

Penulisan Surat Izin Praktek (SIP) dokter hanya mencapai $57,14 \%$, dimana dalam resep wajib mencantumkan SIP dokter untuk menjamin keamanan pasien bahwa dokter yang bersangkutan mempunyai hak dan dilindungi undang-undang dalam memberikan pengobatan bagi pasiennya dan telah memenuhi syarat untuk menjalankan praktek seperti yang telah ditetapkan oleh UndangUndang serta untuk menjamin bahwa dokter tersebut secara sah diakui dalam praktek keprofesian dokter [6].

Pencantuman nama, paraf dan nomor telepon dokter dalam resep juga merupakan hal yang penting untuk dicantumkan, jika terjadi kesalahan dalam hal peresepan maka petugas kefarmasian dapat langsung menghubungi dokter yang bersangkutan untuk melakukan verfikasi terkait dengan terapi obat yang diberikan kepada pasien [10].

Dari hasil penelitian, didapatkan bahwa nama dokter telah tercantum pada semua resep namun untuk paraf dan nomor telepon dokter hanya $60 \%$ dan $85,72 \%$ saja yang mencantumkan.

Syarat farmasetis lainnya yang harus dicantumkan dalam resep yaitu tanggal resep. Dari hasi penelitian, $92,86 \%$ resep telah mencantumkan syarat ini. Pencantuman tanggal resep yaitu berkaitan dengan keamanan pasien dan menentukan apakah resep boleh dilayani atau tidak [6].

Apabila ditinjau dari identitas pasien, 97,14\% resep mencantumkan nama pasien. Pencantuman nama 
pasien di dalam resep sangat berguna untuk menghindari tertukarnya obat dengan pasien lain pada waktu pelayanan di apotek. Apabila nama pasien tidak tercantum pada resep, apoteker dapat menanyakan langsung kepada pasien sehingga obat yang diresepkan oleh dokter tidak akan tertukar. Alamat pasien juga menjadi suatu pembeda ketika ada nama pasien yang sama saat menebus resep. Jadi apabila terdapat nama pasien yang sama atau tidak dicantumkan nama pasien pada resep, petugas apotek dapat menanyakan langsung berdasarkan pada alamat pasien, dengan demikian obat yang diresepkan oleh dokter tidak akan tertukar dan apabila salah dalam pemberian obat dapat ditunjukkan ke alamat tersebut.

Data pasien lainnya yang harus dicantumkan dalam resep yaitu umur dan berat badan, yang diperlukan dalam perhitungan dosis khususnya dosis anak [10]. Umur pasien juga berkaitan dengan kesesuaian bentuk sediaan [6]. Dari 70 resep, hanya $54,29 \%$ yang mencantumkan umur pasien dan 2,86\% yang mencantumkan berat badan pasien.

Jenis kelamin merupakan salah satu aspek yang diperlukan dalam perencanaan dosis karena dapat mempengaruhi faktor dosis obat pada pasien. Namun hanya $12,86 \%$ resep yang mencantumkan jenis kelamin pasien.

Berdasarkan penelitian mengenai pengaruh pendampingan apoteker, kesalahan peresepan sebelum dilakukan pendampingan oleh apoteker memiliki nilai paling besar
(78,89\%), sedangkan kesalahan peresepan paling sedikit ditemukan dengan pendampingan apoteker $(11,31 \%)$. Jenis kesalahan penulisan resep terbanyak adalah informasi resep yang tidak lengkap/tidak tertulis $(68,15 \%)$ [11].

Untuk menghindari kesalahan pengobatan, Apoteker dapat berperan nyata dalam pencegahan terjadinya kesalahan pengobatan di Apotek melalui kolaborasi dengan dokter dan pasien. Hal yang dapat dilakukan antara lain [12] :

a. Identifikasi pasien minimal dengan dua identitas, misalnya nama dan nomor rekam medik/ nomor resep,

b. Apoteker tidak boleh membuat asumsi pada saat melakukan interpretasi resep dokter. Untuk mengklarifikasi ketidaktepatan atau ketidakjelasan resep, singkatan, hubungi dokter penulis resep.

c. Dapatkan informasi mengenai pasien sebagai petunjuk penting dalam pengambilan keputusan pemberian obat, seperti :

a) Data demografi (umur, berat badan, jenis kelamin) dan data klinis (alergi, diagnosis dan hamil/menyusui).

Contohnya, Apoteker perlu mengetahui tinggi dan berat badan pasien yang menerima obat-obat dengan indeks terapi sempit untuk keperluan perhitungan dosis. 
b) Hasil pemeriksaan pasien (fungsi organ, hasil laboratorium, tanda-tanda vital dan parameter lainnya). Contohnya, Apoteker harus mengetahui data laboratorium yang penting, terutama untuk obat-obat yang memerlukan penyesuaian dosis dosis (seperti pada penurunan fungsi ginjal).

d. Apoteker harus membuat riwayat/catatan pengobatan pasien.

e. Strategi lain untuk mencegah kesalahan obat dapat dilakukan dengan penggunaan otomatisasi (automatic stop order), sistem komputerisasi (e-prescribing) dan pencatatan pengobatan pasien seperti sudah disebutkan diatas.

f. Permintaan obat secara lisan hanya dapat dilayani dalam keadaan emergensi dan itupun harus dilakukan konfirmasi ulang untuk memastikan obat yang diminta benar, dengan mengeja nama obat serta memastikan dosisnya. Informasi obat yang penting harus diberikan kepada petugas yang meminta/menerima obat tersebut. Petugas yang menerima permintaan harus menulis dengan jelas instruksi lisan setelah mendapat konfirmasi.

\section{KESIMPULAN}

Kelengkapan resep pada peresepan pasien di Apotek X , wilayah Badung tidak memenuhi aspek administrasi berdasarkan Peraturan Menteri Kesehatan No. 73 tahun 2016. Persentase resep yang tidak memenuhi persyaratan administrasi meliputi nama pasien $2,86 \%$, umur pasien $45,71 \%$, jenis kelamin $87,14 \%$, berat badan $97,14 \%$, alamat pasien $51,43 \%$, SIP dokter $42,86 \%$, nomor telepon $14,28 \%$, paraf dokter $40 \%$ dan tanggal resep $7,14 \%$.

\section{UCAPAN TERIMA KASIH}

Pada kesempatan ini penulis mengucapkan terimakasih kepada pihak Apotek X di Kabupaten Badung atas kesempatan yang diberikan hingga terselesaikannya peneitian ini.

\section{DAFTAR PUSTAKA}

[1] Anderson, P. D. The Broad Field of Forensic Pharmacy. Journal of Pharmacy Practice. 2019; 25(1): 7-12.

[2] Wirasuta, M. A. G. Analisis Toksikologi Forensik dan Interpretasi Temuan Analisis. Indonesian Journal of Legal and Forensic Sciences. 2008; 1(1): 47-55.

[3] Kepmenkes Nomor 280/Menkes/SK/V/1981 tentang Ketentuan dan Tata Cara Pengelolaan Apotik

[4] Perwitasari D. A, Abror J, Wahyuningsih I. Medication Errors in Outpatients of A Government Hospital in Yogyakarta Indonesia. International Journal of 
Pharmaceutical Sciences

Review and Research. 2010; 1(1): 8-10.

[5] Anonim. Keputusan Mentri Kesehatan Republik Indonesia Nomor 1027/ Menkes/SK/IX/2004 tentang Standar Pelayanan Kefarmasian di Apotek. Jakarta: Direktorat Jendral Yanfar dan Alkes Depkes RI; 2004.

[6] Megawati, F., \& Santoso, P. Pengkajian Resep Secara Administratif Berdasarkan Peraturan Menteri Kesehatan RI No 35 Tahun 2014 Pada Resep Dokter Spesialis Kandungan di Apotek Sthira Dhipa. Jurnal Ilmiah Medicamento. 2017; 3(1): 12-16.

[7] Syamsuni, H. A.. Ilmu Resep. Jakarta: Penerbit Buku Kedokteran EGC; 2006.

[8] Permenkes RI. Peraturan Menteri Kesehatan Republik Indonesia No.73 Tahun 2016 tentang Standar Pelayanan Kefarmasian di Apotek. Jakarta: Menteri Kesehatan Republik Indonesia; 2016.

[9] Mamarimbing, M., Fatimawali, F., \& Bodhi, W. Evaluasi Kelengkapan Administratif Resep dari Dokter Spesialis Anak Pada Tiga Apotek di Kota Manado. Pharmacon. 2012; 1(2).

[10] Jaelani, A. K., \& Hindratni, F. Gambaran Skrining Resep Pasien Rawat Jalan Di Puskesmas Kota Yogyakarta Tahun 2015. Jurnal Endurance. 2017; 2(1): 1-6.
[11] Turnodihardjo, M. A., Hakim, L., \& Kartikawatiningsih, D. Artikel Penelitian Pengaruh Pendampingan Apoteker Saat Visite Dokter terhadap Kesalahan Peresepan di Ruang Perawatan Intensif. Indonesian Journal of Clinical Pharmacy. 2016; 5(3): 160-168.

[12] Depkes RI. Tanggung Jawab Apoteker Terhadap Keselamatan Pasien (Patient Safety). Jakarta: Departemen Kesehatan Republik Indonesia; 2008. 